\title{
The "common soil" theory: coronary disease, diabetes and inflammation
}

\begin{abstract}
"Type 2 (non-insulin-dependent) diabetes mellitus and coronary heart disease: chicken, egg, or neither?": this was the question posed by Jarrett in 1984, on the basis of the knowledge available at that time that the risk of coronary disease was greater among individuals who had recently become diabetic than among those whose disease had been known of and diagnosed for a longer time. ${ }^{1}$ In 1995 , Stern put forward the idea that diabetes and coronary disease both came from a "common soil". ${ }^{2}$ The basis for this was the early environment theory for both diabetes and coronary disease, which started to gain strength and publicity through the publications of Barker et al., who described how, in the United Kingdom, regions that had presented high rates of infant mortality 50 years earlier were the ones with greater prevalence of diabetes and incidence of coronary disease decades later. ${ }^{3}$ Subsequently, they showed that inadequate nutritional conditions during the perinatal period were associated with increased incidence of hypertension, diabetes and coronary disease..$^{4-6}$ Barker et al. put forward the hypothesis that fetal malnutrition could lead to some type of misregulation in pancreatic beta cells and, at the same time, malnutrition would give rise to fewer adipocytes, which in a subsequent situation with an excess of calorie offer would tend to cause hypertrophy in these cells, with undesired metabolic consequences. ${ }^{3}$
\end{abstract}

During this same period, the description by Reaven of the "X syndrome" also gained form and publicity. This subsequently became known as insulin resistance syndrome. ${ }^{7}$ The creation of this theory placed abdominal obesity as the basis for concomitant appearance of arterial hypertension, glucose intolerance and dyslipidemia (later on, this would be the combination of high triglycerides and lowering of the high-density lipoprotein fraction of cholesterol). Such observations are believed to have been started in France in the 1940s, by Jean Vague in the periodical La Presse Medicale in 1947 (vol. 55, p. 339-40) and 1949 (vol. 57, p. 556-7 e 835-7). These were published in French, and their first presentation in English, in 1956, did not receive the attention they were due. ${ }^{8}$ The first publications to associate abdominal obesity with diabetes and coronary disease came from the results of a 17-year follow-up of a cohort of men born in Gothenburg (Sweden) in 1913. These studies showed that regional adiposity presented a greater causal relationship with both coronary disease and with diabetes than did the body mass index. ${ }^{9,10}$

In the 1990s, other findings showed that the intersection between diabetes and coronary disease went a bit beyond a mere cause-effect relationship such as the one that exists between the smoking habit and the incidence of lung cancer, for example. One interesting development was that the counter-intuitive effect of moderate use of alcoholic drinks as a protective factor against angina pectoris and myocardial infarction ${ }^{11}$ was also described in relation to the incidence of diabetes. ${ }^{12}$ Along the same lines, the moderate use of alcoholic drinks by diabetics reduced their risk that coronary diseases might appear to a similar extent as observed among non-diabetics who drank regularly. ${ }^{13,14}$ Another relevant description that is still controversial came from a study carried out in Finland, which showed that the mortality due to coronary disease had similar rates among participants with diabetes but without coronary disease and among those with coronary disease but without diabetes. ${ }^{15}$ These findings were not repeated in other cohorts studied, but the impact of the length of time with diabetes greatly collaborated towards bringing together the risk of death due to coronary disease between diabetics without previous history of coronary disease and individuals with the disease but without diabetes. ${ }^{16-18}$ However, there is no divergence with regard to the fact that an association between previous diagnoses of diabetes and coronary disease increases the risk of death tenfold, in comparison with individuals without such conditions. One effect on the demographic indicators may be the slowing down of the fall in mortality due to coronary disease due to the impact of diabetes and obesity, a situation that has been described in the United States and also in the metropolitan regions of Brazil. ${ }^{19,20}$

Since the end of the 1980s, the comprehension that regional adiposity is an independent risk factor of great importance with regard to the appearance of both diabetes and coronary heart disease has consolidated in such a way that a new disease, the "metabolic syndrome", has become incorporated into medical jargon in substitution for the old "X syndrome". In addition to the states already cited (abdominal obesity, dyslipidemia, hypertension and glucose intolerance), pro-thrombolytic and pro-inflammatory states also appear in the new definition. ${ }^{21}$ Subsequent to this, a new and fascinating field of research opened up that was associated both with diabetes and with coronary disease: the inflammatory process that underlies and perhaps is at the origin of both processes. ${ }^{22-26}$

Considering the impact of obesity and diabetes on our environment, studies focusing on the inflammatory process in the genesis of both these diseases will be very welcome.

Paulo Andrade Lotufo, MD, Dr PH. Superintendent of Hospital Universitário (HU) and associate professor of the School of Medicine, Universidade de São Paulo (FMUSP). Editor of the journals São Paulo Medical Journal and Diagnóstico \& Tratamento. 
1. Jarrett RJ. Type 2 (non-insulin-dependent) diabetes mellitus and coronary heart disease-chicken, egg or neither? Diabetologia. 1984;26(2):99-102.

2. Stern MP. Diabetes and cardiovascular disease. The "common soil" hypothesis. Diabetes. 1995;44(4):369-74.

3. Barker DJ, Osmond C. Infant mortality, childhood nutrition, and ischaemic heart disease in England and Wales. Lancet. 1986;1(8489):1077-81.

4. Barker DJ, Hales CN, Fall CH, Osmond C, Phipps K, Clark PM. Type 2 (non-insulin-dependent) diabetes mellitus, hypertension, and hyperlipidaemia (syndrome $\mathrm{X}$ ): relation to reduced fetal growth. Diabetologia. 1993;36(1):62-7.

5. Hales CN, Barker DJ, Clark PM, Cox LJ, Fall C, Osmond C, et al. Fetal and infant growth and impaired glucose tolerance at age 64. BMJ. 1991;303(6809):1019-22.

6. Barker DJ, Winter PD, Osmond C, Margetts B, Simmonds SJ. Weight in infancy and death from ischaemic heart disease. Lancet. 1989;2(8663):577-80

7. Reaven GM. Banting lecture 1988. Role of insulin resistance in human disease. Diabetes. 1988;37(12):1595-607.

8. Vague J. The degree of masculine differentiation of obesities: factor determining predisposition to diabetes, atherosclerosis, gout, and uric calculous disease. Am J Clin Nutr. 1956;4(1):2034.

9. Larsson B, Svardsudd K, Welin L, Wilhelmsen L, Bjorntorp P, Tibblin G. Abdominal adipose tissue distribution, obesity, and risk of cardiovascular disease and death: 13 year follow up of participants in the study of men born in 1913. Br Med J (Clin Res Ed). 1984;288(6428):1401-4.

10. Ohlson LO, Larsson B, Svardsudd K, et al. The influence of body fat distribution on the incidence of diabetes mellitus. 13.5 years of follow-up of the participants in the study of men born in 1913. Diabetes. 1985;34(10):1055-8.
11. Camargo CA Jr, Stampfer MJ, Glynn RJ, et al. Moderate alcohol consumption and risk for angina pectoris or myocardial infarction in U.S. male physicians. Ann Intern Med. 1997;126(5):372-5

12. Ajani UA, Hennekens $\mathrm{CH}$, Spelsberg A, Manson JE. Alcohol consumption and risk of type 2 diabetes mellitus among US male physicians. Arch Intern Med. 2000;160(7):1025-30.

13. Ajani UA, Gaziano JM, Lotufo PA, et al. Alcohol consumption and risk of coronary heart disease by diabetes status. Circulation. 2000;102(5):500-5

14. Valmadrid CT, Klein R, Moss SE, Klein BE, Cruickshanks $\mathrm{KJ}$. Alcohol intake and the risk of coronary heart disease mortality in persons with older-onset diabetes mellitus. JAMA. 1999;282(3):239-46.

15. Haffner SM, Lehto S, Ronnemaa T, Pyorala K, Laakso M. Mortality from coronary heart disease in subjects with type 2 diabetes and in nondiabetic subjects with and without prior myocardial infarction. N Engl J Med. 1998;339(4):229-34.

16. Lotufo PA, Gaziano JM, Chae CU, et al. Diabetes and all-cause and coronary heart disease mortality among US male physicians. Arch Intern Med. 2001;161:242-7.

17. Hu FB, Stampfer MJ, Solomon CG, et al. The impact of diabetes mellitus on mortality from all causes and coronary heart disease in women: 20 years of follow-up. Arch Intern Med. 2001;161(14):1717-23.

18. Cho E, Rimm EB, Stampfer MJ, Willett WC, Hu FB. The impact of diabetes mellitus and prior myocardial infarction on mortality from all causes and from coronary heart disease in men. J Am Coll Cardiol. 2002;40(5):954-60.

19. Gu K, Cowie CC, Harris MI. Diabetes and decline in hear disease mortality in US adults. JAMA. 1999;281(14):1291-7.

20. Lotufo PA Increasing obesity in Brazil: predicting a new peak o cardiovascular mortality. Sao Paulo Med J. 2000;118(6):161-2.
21. Grundy SM, Brewer HB Jr, Cleeman JI, Smith SC Jr, Lenfant C; American Heart Association; National Heart, Lung, and Blood Institute. Definition of metabolic syndrome: Report of the National Heart, Lung, and Blood Institute/American Hear Association conference on scientific issues related to definition. Circulation. 2004 27;109(3):433-8

22. Schmidt MI, Duncan BB, Sharrett AR, et al. Markers of inflammation and prediction of diabetes mellitus in adults (Atherosclerosis Risk in Communities study): a cohort study. Lancet. 1999;353(9165):1649-52.

23. Saito I, Folsom AR, Brancati FL, Duncan BB, Chambless LE, McGovern PG. Nontraditional risk factors for coronary hear disease incidence among persons with diabetes: the Atherosclerosis Risk in Communities (ARIC) Study. Ann Intern Med. 2000;133(2):81-91.

24. Duncan BB, Schmidt MI, Pankow JS, et al. Low-grade systemic inflammation and the development of type 2 diabetes: the atherosclerosis risk in communities study. Diabetes. 2003;52(7):1799-805.

25. Duncan BB, Schmidt MI. Chronic activation of the innate immune system may underlie the metabolic syndrome. Sao Paulo Med J. 2001;119(3):122-7.

26. Schmidt MI, Duncan BB. Diabesity: an inflammatory metabolic condition. Clin Chem Lab Med. 2003;41(9):1120-30

Note: This article was originally published in Portuguese in the Journal Diagnóstico \& Tratamento: Lotufo PA. A teoria do "solo comum": doença coronária, diabetes e inflamação. Diagn Tratamento. 2005;10(3):23-4. 